\title{
LOCAL INSTITUTIONS AS A DETERMINANT OF RURAL DEVELOPMENT IN POLAND - A CASE STUDY OF GREATER POLAND VOIVODESHIP
}

\author{
Natalia Bartkowiak-Bakun ${ }^{1}$ \\ Poznan University of Life Sciences Poland
}

\begin{abstract}
The main aim of the study was to verify relations between the level of socioeconomic development and the quality of local government institutions. The spatial range of the study comprised Greater Poland as an administrative region, i.e. Greater Poland Voivodeship. Rural and rural-urban communes were the subjects of the study. The research spanned the period of 2016. The empirical research material was acquired from a questionnaire survey (2011) and Local Data Bank. The research procedure consisted of the following steps: 1. measurement of the socioeconomic development and quality of institutions; 2 . determination of relations between the level of development and quality of institutions. Development was measured by means of the synthetic trait. The relation was investigated by means of analysis of variance (ANOVA). The research results showed that institutions were the determinant strengthening development (the high quality of institutions coincided with high socioeconomic development). The quality of institutions was significantly diversified according to the level of development.
\end{abstract}

Key words: local development, institutions, rural areas, Greater Poland Voivodeship.

JEL code: O43, Q15

\section{Introduction}

New institutional economics (NIE) has bridged a significant gap in neoclassical economics. The NIE programme assumes that the institutional structure of economics and society is a determinant of market processes. Therefore, institutions should be the main of research object. According to the thesis that institutions have significance, the NIE attempts to economically explain the existence, development and changes of institutions (Hockuba Z., 2001, p. 11).

The criticism of excessive growth of countries and ineffective solutions to problems open the way to reflection on searching for efficient and effective institutional bases of the state (Wilkin J., 2013). It was a key priority to build the market rather than state institutions in the countries which were undergoing system transformations in the early 1990s (Hardt L., 2013). It was assumed that institutions would develop spontaneously as consequence of the market mechanism. Poland's accession to the EU in 2004 was a formal test of the new institutional order, which was established as a result of the system transformation (Wilkin J., 2013, p. 20). Rodrik D. (2003, p. 12) stresses that good institutions can be introduced but it often requires experimentation, readiness to abandon orthodox solutions and paying attention to local conditions. The main aim of the study was to verify relations between the level of socioeconomic development and the quality of local government institutions. According to Wilkin J. (2013), good institutions stimulate actions favouring the possibility to satisfy individual and collective needs, trigger initiative and innovativeness, improve the effectiveness and efficiency of actions taken by individuals and group entities. Good institutions should fulfil specific functions; for example, they should help to transfer information, define and secure proprietary rights and contracts as well as improve competitiveness (Milaszewicz D., 2011).

\section{Research method}

The spatial range of the study encompasses Greater Poland, understood as an administrative region, i.e. Greater Poland Voivodeship. Rural communes and rural-urban communes in Greater Poland Voivodeship will be the research subject encompassing 117 rural communes and 90 ruralurban communes. The empirical material was obtained from the following sources: the Local Data 
Bank of the Central Statistical Office, data from a survey questionnaire (2011).Measurements referred to 2016. The research procedure consisted of the following steps: 1 . measurement of the socioeconomic development and quality of institutions; 2 . determination of relations between the level of development and quality of institutions.

The object of the study was the development of rural areas in Greater Poland Voivodeship, which was identified by comparison of the synthetic features of the following factors: location rent, technical infrastructure, social infrastructure, human capital, social capital and local finance (Table 1).

Table 1

\section{Indicators for socioeconomic development of rural areas in Greater Poland Voivodeship}

\begin{tabular}{|c|c|}
\hline Factor & Indicator \\
\hline Location rent & $\begin{array}{l}\text { The soil quality indicator (points) } \\
\text { The indicator of economic activity (points) } \\
\text { The restrictions in preservation areas (points) } \\
\text { The indicator of road junction location (points) } \\
\text { The indicator of town location (points) } \\
\text { Areas of special nature value under legal protection (in \% of total area) } \\
\text { Forest cover in \% }\end{array}$ \\
\hline Social infrastructure & $\begin{array}{l}\text { Nursery schools per } 100 \mathrm{~km}^{2} \\
\text { Primary schools per } 100 \mathrm{~km}^{2} \\
\text { Lower secondary schools per } 100 \mathrm{~km}^{2} \\
\text { Public libraries per } 1000 \text { population } \\
\text { Out-patient departments per } 1000 \text { population } \\
\text { Number of population per pharmacy }\end{array}$ \\
\hline $\begin{array}{l}\text { Technical } \\
\text { infrastructure }\end{array}$ & $\begin{array}{l}\text { Water -line distribution network in } \mathrm{km} / 100 \mathrm{~km}^{2} \\
\text { Sewerage distribution network in } \mathrm{km} / 100 \mathrm{~km}^{2} \\
\text { Relations between connections leading water supply/sewage } \\
\text { Gas-line distribution network in } \mathrm{km} / 100 \mathrm{~km}^{2} \\
\text { Expenditures on public roads in total expenditures amounted (in \%) }\end{array}$ \\
\hline Human capital & $\begin{array}{l}\text { Population per } 1 \mathrm{~km}^{2} \\
\text { Relation children-oldest } \\
\text { Live births per } 1000 \text { women in } 15-49 \text { years } \\
\text { Natural increase per } 1000 \text { population } \\
\text { Migration per } 1000 \text { population } \\
\text { Females per } 100 \text { males ( } 25-29 \text { years) } \\
\text { Tertiary education (in \%) }\end{array}$ \\
\hline Social capital & $\begin{array}{l}\text { Entities of the national economy in the REGON register per } 1000 \text { population } \\
\text { Associations and other social organizations per } 1000 \text { population } \\
\text { Voter turnout (in \%) } \\
\text { Expenditures on culture per capita (zl) } \\
\text { Expenditures on physical culture and sports per capita(zl) }\end{array}$ \\
\hline Local finance & $\begin{array}{l}\text { Total income zloty per capita (zl) } \\
\text { EU funds zloty per capita (zl) } \\
\text { Investment expenditures in total expenditures amounted (in \%) } \\
\text { Own income in total income amounted (in \%) }\end{array}$ \\
\hline
\end{tabular}

The construction of the synthetic feature was made according to the methodology suggested by Wysocki \& Lira (2005). The selection of simple features was made according to the formal, substantive and statistical criteria, which are the determinants of development. The data were checked for their completeness, measurability and availability. The variability coefficient and 
Pearson's correlation coefficient were used as the basis for assessment of statistical premises. The former was enable elimination of the variables with low information value from the set, whereas the latter was used to assess the strength of correlation between the variables. The analysis also comprised the diagonal elements of inverse matrix to correlation matrix $\mathrm{R}$ in order to check the correctness of the condition numbers of the matrices.

The next step was to involve normalisation of the values of simple features (unitization is proposed), which consists in unification of the character and making the feature values comparable by removing their nominals and unification of the lines of values.

Table 2

The measure of assessment of local government institutions

\begin{tabular}{|c|c|c|c|c|}
\hline Criterion & $\begin{array}{l}\text { Traits characterising } \\
\text { quality of local institutions }\end{array}$ & Weight & Rating & $\begin{array}{l}\text { Weighted } \\
\text { value }\end{array}$ \\
\hline \multirow{4}{*}{ International cooperation } & Number of partner communes & 0.3 & & \\
\hline & Area of cooperation & 0.4 & & \\
\hline & Frequency of cooperation & 0.3 & & \\
\hline & $\begin{array}{l}\text { Weight of total rating of local } \\
\text { authorities' activity }\end{array}$ & 0.15 & & \\
\hline \multirow{4}{*}{ Domestic cooperation } & Subjects of cooperation & 0.3 & & \\
\hline & Joining a union or association & 0.1 & & \\
\hline & Subject of joint tasks & 0.6 & & \\
\hline & $\begin{array}{l}\text { Weight of total rating of local } \\
\text { authorities' activity }\end{array}$ & 0.2 & & \\
\hline \multirow{3}{*}{ Entrepreneurship } & $\begin{array}{l}\text { Organisational unit and } \\
\text { training }\end{array}$ & 0.5 & & \\
\hline & $\begin{array}{l}\text { Institutions supporting } \\
\text { entrepreneurship }\end{array}$ & 0.5 & & \\
\hline & $\begin{array}{l}\text { Weight of total rating of local } \\
\text { authorities' activity }\end{array}$ & 0.1 & & \\
\hline \multirow{3}{*}{ Non-governmental organisations } & Organisational unit & 0.5 & & \\
\hline & Declaration of cooperation & 0.5 & & \\
\hline & $\begin{array}{l}\text { Weight of total rating of local } \\
\text { authorities' activity }\end{array}$ & 0.1 & & \\
\hline \multirow{3}{*}{ External sources of finance } & Application activity & 0.4 & & \\
\hline & Joint initiatives & 0.6 & & \\
\hline & $\begin{array}{l}\text { Weight of total rating of local } \\
\text { authorities' activity }\end{array}$ & 0.3 & & \\
\hline
\end{tabular}

Source: author's elaboration based on Rosner A., 1997; Heffner K., 2002;Klodzinski M., 2006; Rosner A., Stanny M., 2007; Stanny M., 2010; Skorupska 2005, Bartkowiak N., Poczta W.,2012,

Institutions are evaluated according to their functions, implementation of distributive issues and creation of stimuli decreasing precariousness and strengthening the market (Aron J., 2000, p. 106). However, the main goal is to evaluate existing institutions and answer the question about the characteristics of 'good' institutions, which is equivalent to assessment of their quality.

The quality of institutions was assessed in the following areas: international cooperation, cooperation with other entities, conditions for the development of entrepreneurship and acquisition of external funds. The data were acquired from a questionnaire survey conducted among the staff employed at local government institutions in all communes of Greater Poland Voivodeship in 2011. Table 2 includes elements of assessment of the institutions and the method of construction of the measure. 
In order to verify the hypotheses with statistically significant equal averages, due to the selected criterion of the division of communes (development level), the analysis of ANOVA variance was extended with applying the Tukey post-hoc test.

\section{Research results and discussion}

\section{Characterisation of rural areas in Greater Poland Voivodeship}

The measurement of the socioeconomic development enabled classification of rural areas in Greater Poland. They were divided into four classes differing in the level of development. Figure 1 shows the spatial diversification of the grouping. Class 1 consists of 21 communes $(10 \%)$ characterised by high level of development. As the spatial distribution shows, these communes are situated in the zone of influence of the city of Poznan. The other individual communes in this class are located in the south of the region. The components of analysis achieved the highest values in this group - some of them were much greater than average. This class was characterised by a very good location rent and good condition of local finance. The communes were characterised by high financial independence (high share of own income). This situation enabled investments in the technical and social infrastructure, which translated into very good living and development conditions for the commune inhabitants. These areas were characterised by high values of the entrepreneurship indicator and positive population balance. These areas are attractive for business and as places of residence.

The second group consists of 66 communes ( $32 \%$ ) characterised by upper intermediate level of development. The areas are located in the second ring surrounding Poznan, south of this city, stretching along part of the trunk road 11. Apart from that, this class included relatively large numbers of communes located around the subregional towns of Leszno and Konin. In comparison with class 1 , these communes were characterised by worse financial situation, especially lesser financial independence, lower income and lower investment potential. This situation resulted in the average level of infrastructure. The biggest differences were noted in the inhabitants' access to sewage and gas networks, nursery schools and health service. As far as the human and social capital are concerned, the values in this class were similar to those in class 1 . These areas need further investments so that their infrastructure will meet the inhabitants' expectations.

In nearly a half of rural areas in Greater Poland (99 communes, $48 \%$ of the total number) the level of development was lower than average. The areas are relatively equally distributed around the region, but most of them are located in the north and east. Apart from the human capital, the values of all the other components were below the average level. The primary condition of the level of development in these communes is their location rent. These areas are characterised by worse conditions for the development of agriculture and low spatial accessibility. They are less populated. The natural barriers, such as forests and lakes, result in worse infrastructure in these areas. The costs of their development are higher than average. The condition of local finance, low income and low financial independence are considerable limitations to investments and changes in the situation of these communes. They have a chance for development if the local authorities acquire external funds. This might trigger the endogenic resources of these communes. 


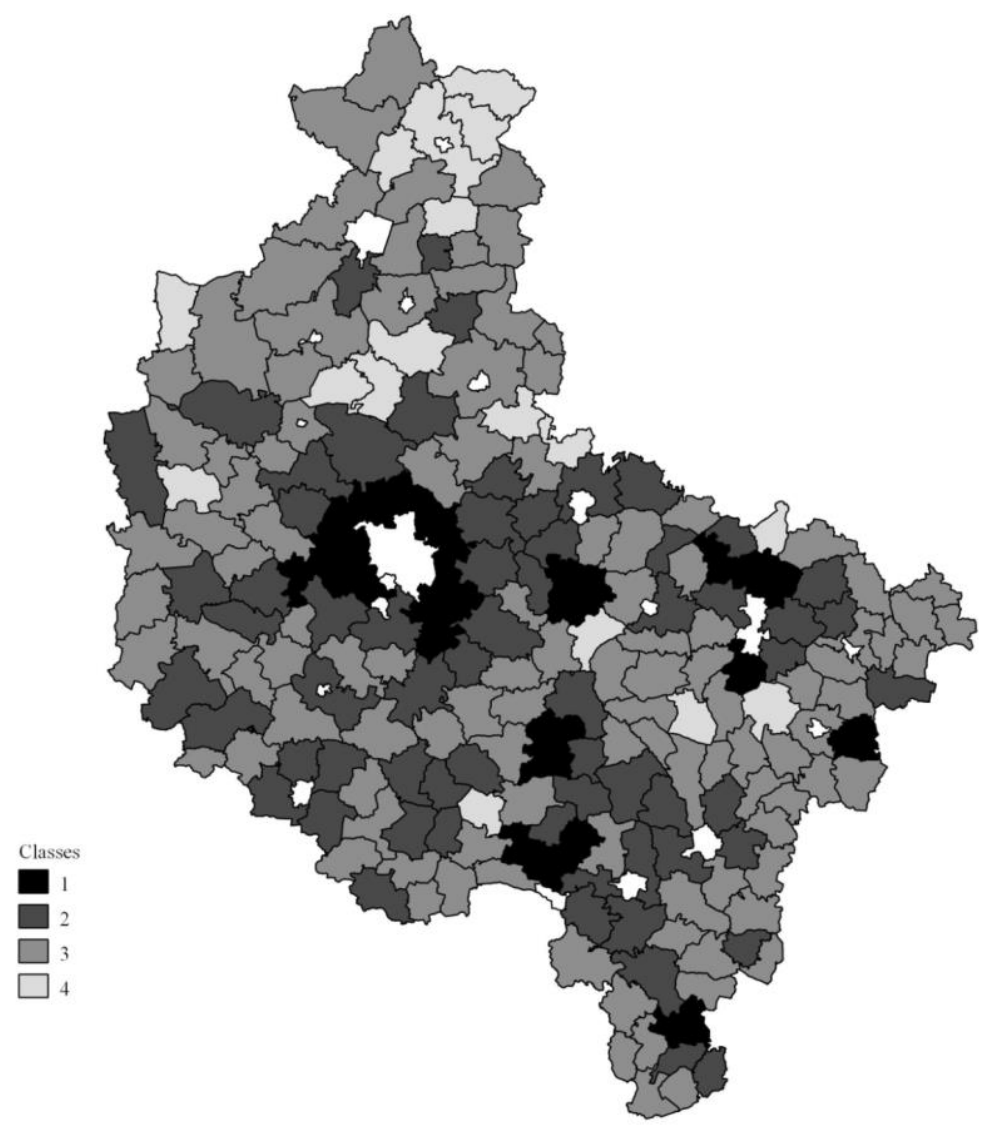

Source: author's elaboration

Fig. 1 Spatial diversification of socioeconomic development of rural areas in Greater Poland Voivodeship

Class 4 consists of 21 communes (10\%) characterised by low level of development. The communes are located far away from Poznan, on the outskirts of the region, with few of them located inside the region. These are problem areas due to the deficit in their infrastructure (especially sewage and gas networks), low spatial accessibility and poor quality of roads. Additionally, these areas do not have their own investment capacity due to the poor condition of local finance. Thus, the infrastructural gap is growing due to the accumulation of negative feedbacks. For this reason, these areas should remain within the zone of influence of the regional and rural policies to overcome their peripheral character and trigger their local potential. The active influence of regional authorities on these entities will enable implementation of the sustainable development policy and it may prevent further marginalisation or exclusion of these areas.

\section{The quality of institutions in rural areas}

The quality of institutions was measured in order to identify their significance to the socioeconomic development of rural areas. As was assumed, the research concentrated on formal institutions (local authorities and commune councils) in selected areas, especially on the good institution attribute, which is manifested by the capacity to generate development stimuli. Table 3 shows the values of components of the quality of institutions in relation to the socioeconomic development classes.

The analysis of variance (ANOVA) was used to investigate the quality of institutions according to the level of socioeconomic development. The analysis proved the significance of differences between the mean values in each three of the five areas under analysis. There were no significant 
differences between the mean values referring to the development classes in the areas of international cooperation and cooperation with non-governmental organisations. The lack of significant differences in these areas resulted from the communes' lesser interest in this activity when Poland joined the European Union. In fact, many formal partnerships do not function in practice. As far as the area related with the triggering of grassroots resources, such as nongovernmental organisations, is concerned, it is difficult to analyse it with measurable indicators. However, on the other hand, commune authorities are gaining skills in effective delegation of their tasks to non-governmental organisations. As far as the other three areas with significant differences between the classes are concerned, there were high values in the class of welldeveloped communes. The aspect of domestic cooperation with other entities is very often decisive to the access to information, knowledge and the possibility to lobby for one's own initiatives (projects). By contrast, this aspect is a weak point of poorly developed communes. The quality of institutions categorised as the area of initiation of entrepreneurial attitudes and cooperation with entrepreneurs also reached the highest values in the communes characterised by the high level of development. If we consider the possibility to make investments financed from one's own resources, it is the acquisition of funds from the European Union as well as the effective activity of institutions in this area that are of key importance. Budget limitations and the investment prefinancing system are the limiting factors in the communes characterised by the lower intermediate and low level of development. In consequence, the entities which do not have funds to secure their own contribution and the investment are excluded from the process or their possibilities of development are considerably limited.

Table 3

The quality of institutions in relation to the socioeconomic development classes

\begin{tabular}{|l|c|c|c|c|c|}
\hline Classes & $\begin{array}{c}\text { International } \\
\text { cooperation }\end{array}$ & $\begin{array}{c}\text { Domestic } \\
\text { cooperation }\end{array}$ & Entrepreneurship & $\begin{array}{c}\text { Non-governmental } \\
\text { organisations }\end{array}$ & $\begin{array}{c}\text { External } \\
\text { sources of } \\
\text { finance }\end{array}$ \\
\hline $\mathbf{1}$ & 0.51 & 0.65 & 0.57 & 0.25 & 0.42 \\
\hline $\mathbf{2}$ & 0.52 & 0.44 & 0.42 & 0.29 & 0.50 \\
\hline $\mathbf{3}$ & 0.51 & 0.35 & 0.48 & 0.26 & 0.41 \\
\hline $\mathbf{4}$ & 0.49 & 0.38 & 0.57 & 0.29 & 0.44 \\
\hline Average & $\mathbf{0 . 5 1}$ & $\mathbf{0 . 4 2}$ & $\mathbf{0 . 5 0}$ & $\mathbf{0 . 2 7}$ & $\mathbf{0 . 4 4}$ \\
\hline
\end{tabular}

Source: author's calculations based on data from a survey questionnaire (2011)

Table 4

The analysis of variance concerning the quality of institutions in the areas analysed in terms of the level of socioeconomic development

\begin{tabular}{|c|c|c|}
\hline Specification & $\mathbf{F}$ & $\mathbf{p}$ \\
\hline International cooperation & 0.058 & 0.982 \\
\hline Domestic cooperation & 5.038 & 0.002 \\
\hline Entrepreneurship & 5.905 & 0.001 \\
\hline Non-governmental organisations & 0.572 & 0.634 \\
\hline External sources of finance & 2.793 & 0.041 \\
\hline
\end{tabular}

Source: author's calculations based on Statistica

The post hoc tests proved that the null hypothesis about the equality of mean values in individual classes should be rejected due to the considerable deviations of the values of indicators 
in class 1 (international cooperation, entrepreneurship) and in class 3 (external sources of financing). The results of the analysis of variance are shown in Table 4.

The quality (and its individual areas) of institutions as a determinant of rural development should be considered together with other conditions, which affect the state of institutions with different impact and direction. It is noteworthy that the results showed that the quality of institutions was characterised by high individuality. The communes with good institutions neighboured the poorest ones. It is necessary to continue the research to understand the mechanisms of local development, especially in institutions.

\section{Discussion}

Economists generally accept the thesis that institutional changes have considerable influence on economic growth and other effects of management. In spite of this fact, so far the mechanism of relations between them has not been thoroughly investigated or described (Wilkin J., 2016; Wojtyna A., 2007). The results of the international research project conducted by Rodrik et al. (2003) proved that the quality of institutions was key to the understanding of the causes of a particular country's successful development. On the other hand, public institutions play an important role in stimulation of economic growth and their appropriate selection may help to overcome unfavourable geographical conditions (Rodrik D., 2003; Wilkin J., 2016, pp. 129-130). The research chiefly concentrates on analysing the influence of institutions on the economic growth rate and explaining differences in this rate on the international scale and in long-term perspective (Kondratowicz A., 2014). The most important studies on the subject are: Keefer P., Knack S., 1995; Barro R. J., 2000; Sala-i-Martin X., 1997; Scully G., 1988; Lawson R., 2006; Justesen M., 2008; Aixala J., Fabro G., 2009; Hall J., Sobel R., Crowley G., 2010; Azman-Saini W., Baharumshah A., Law S., 2010.

The research task will bridge the gap in reference literature. It may enrich the methodology of research on institutions, which is an important element postulated by representatives of new institutional economics. Simultaneously, the author will search for the determinant s of the quality of institutions, which will be a cognitive contribution to the attempt to identify the mechanisms leading from higher quality institutions to higher level of development.

\section{Conclusions, proposals, recommendations}

The development or rural areas Greater Poland Voivodeship is significantly diversified. This diversity is mostly caused by endogenic factors (location rent), which affect other aspects of development. The areas characterised by high level of development are located within the zone of influence of the regional city as well as subregional centres. This fact proves that cities are significant to rural development, especially their nearest surroundings.

At the other end of the distribution there are areas facing the risk of marginalisation or exclusion from development. The share of these communes amounted to $10 \%$. There were numerous negative feedbacks - the peripheral location coincided with poor conditions for agricultural development, poor demographic situation and infrastructure. The infrastructural gap cannot be bridged by grassroots initiatives due to the poor condition of local finance.

The quality of local institutions is significantly diversified. There are good institutions in the areas characterised by high level of development. The quality of institutions decreased along with the level of development. The dependence relation was not sufficiently identified in the research. 
Therefore, it should be continued to find the mechanisms leading from the better quality of institutions to higher development.

To sum up, the rural policy should be not only territorially oriented but it should also strengthen local institutions in the least developed areas.

\section{Bibliography}

1. Aixala, J. and Fabro, G. (2009). Economic Freedom, Civil Liberties, Political Rights and Growth: a Causality Analysis. Spanish Economic Review, 11(3): 165-178.

2. Aron, J. (2000). Growth and Institutions: A Review of the Evidence, The World Bank Research observer, 15 (1). 1203-1228.

3. Azman-Saini, W., Baharumshah, A. , Law, S. (2010). Foreign Direct Investment, Economic Freedom and Economic Growth: International Evidence. Economic Modelling, 27(5): 1079-1089.

4. Barro, R. J. (2000). Rule of Law, Democracy, and Economic Performance. In 2000 Index of Economic Freedom (Washington, D.C.: The Heritage Foundation).

5. Bartkowiak N., Poczta W. (2012). Czynniki rozwoju obszaow wiejskich w Wielkopolsce, Wydawnictwo UP w Poznaniu, Poznan.

6. Hall, J., Sobel, R., Crowley, G. (2010). Institutions, Capital, and Growth.Southern Economic Journal, 77(2): 385-405.

7. Hard, L. (2013). Optymalnosc instytucji w perspektywie implementacji zasad dobrego rzadzenia. W: Jakosc rzadzenia w Polsce. Jak ja badac, monitorowac i poprawiac? Wydawnictwo Naukowe SCHOLAR, Warszawa.

8. Heffner, K. (2002). Czynniki osadnicze wpływajace na potencjal rozwojowy obszarow wiejskich [w:] Wiejskie obszary kumulacji barier rozwojowych, A. Rosner (red.). Polska Akademia Nauk Instytut Rozwoju Wsi i Rolnictwa, Warszawa.

9. Hockuba, Z. (2001). Nowa ekonomia instytucjonalna-czy zdominuje nasze myslenie w rozpoczynajacym sie stuleciu?: VII Kongres Ekonomistow Polskich, Czy Ekonomia Nadaza z Wyjasnieniem Rzeczywistosci) / Sesja I. Z. 2, PTE, Warszawa.

10. Jakosc rzadzenia w Polsce. Jak ja badac, monitorowac i poprawiac?, Wilkin, J. (ed), 2013,Wydawnictwo Naukowe Scholar, Warszawa.

11. Justesen, M. (2008). The Effect of Economic Freedom on Growth Revisited: New Evidence on Causality from a Panel of Countries 1970-1999. European Journal of Political Economy, 24(3): 642-660.

12. Keefer, P., Knack, S. (1995). Institutions and Economic Performance: Cross-Country Tests Using Alternative Institutional Measures. Economics and Politics,7: 207-227.

13. Klodzinski, M. (2006). Aktywizacja spoleczno-gospodarcza gmin wiejskich i malych miast, IRWiR PAN, Warszawa.

14. Kondratowicz, A. (2014). Wolnsc gospodarcza a teoria zmiany instytucjonalnej, IX kongres Ekonomistow, http://blog.narotama.ac.id/wpcontent/uploads/2014/11/WOLNO \%C5 \%9A \%C4 \%86GOSPODARCZA-A-TEORIA-ZMIANY-INSTYTUCJONALNEJ.pdf

15. Lawson, R. (2006). On Testing the Connection between Economic Freedom and Growth. Econ Journal Watch 3(3): 398-406.

16. Milaszewicz, D. (2011). Jakosc instytucji a wzrost gospodarczy. Studia i Prace WNEiZ nr 19/2011, Szczecin.

17. Rodrik, D. (2003). "What do We Learn from Country Narratives?" en D. Rodrik (ed), In Search of Prosperity. Analytic Narratives on Economic Growth, Princeton, Princeton University Press.

18. Rosner A., Stanny M., (2007): Zroznicowanie poziomu rozwoju obszarow wiejskich w Polsce wedlug komponentu spolecznego [in:] Zroznicowanie poziomu rozwoju spoleczno-gospodarczego obszarow wiejskich a zroznicowanie dynamiki przemian, A. Rosner (ed), Instytut Rozwoju Wsi i Rolnictwa PAN, Warszawa.

19. Rosner, A. (1997). Niektore specyficzne składniki „zasobu” gminy [w:] Ekonomiczne i spoleczne uwarunkowania i mozliwosci wielofunkcyjnego rozwoju wsi w Polsce, en. M. Klodzinski, A. Rosner (ed), Wydawnictwo SGGW, Warszawa.

20.Sala-i-Martin, X. (1997). I Just Ran Two Million Regressions. American Economic Review 87(2): 178-183.

21.Scully, G. (1988). The Institutional Framework and Economic Development. Journal of Political Economy

22. Skorupska, A. (2005): Wspolpraca miedzynarodowa samorzadu gminnego na podstawie badan [in:] Wspolpraca miedzynarodowa samorzadu gminnego A. Skorupska (ed), Polski Instytut Spraw Miedzynarodowych, Warszawa.

23.Stanny, M. (2010): Ludnosc i jej aktywnosc zawodowa - tendencje zmian na obszarach wiejskich [in:] Przestrzenne, spoleczno-ekonomiczne zroznicowanie obszarow wiejskich w Polsce, M. Stanny i M. Drygas (ed). Instytut Rozwoju Wsi i Rolnictwa Polskiej Akademii Nauk, Warszawa.

24. Wilkin, J. (2016): Instytucjonalne i kulturowe podstawy gospodarowania. Humanistyczna perspektywa ekonomii. Wydawnictwo Naukowe Scholar, Warszawa.

25. Wojtyna, A. (2007). Teoretyczny wymiar zaleznosci miedzy zmianami instytucjonalnymi, polityka ekonomiczna a wzrostem gospodarczym. Gospodarka Narodowa, 5-6: 1- 23.

26. Wysocki, F., Lira, J. (2005). Statystyka opisowa. Wydawnictwo Akademii Rolniczej w Poznaniu, Poznan. 